\title{
PENGARUH DOSIS ARANG SEKAM DAN PUPUK KANDANG TERHADAP KEPADATAN POPULASI DAN INTENSITAS SERANGAN Spodoptera exigua PADA TANAMAN BAWANG MERAH
}

\author{
Jefri Sembiring*, Andre Prasetya \\ Agroteknologi Fakultas Pertanian Universitas Musamus, 99600 \\ *E-mail: jsembiring@unmus.ac.id
}

Diterima: 17/02/2021

Direvisi: 25/06/2021

Disetujui: 25/06/2021

\begin{abstract}
ABSTRAK
Tanaman bawang merah memiliki permasalahan yang cukup kompleks dalam mempertahankan jumlah produksi. Organisme penggangu tanaman (OPT) merupakan salah satu masalah penting dalam mempertahankan hasil tanaman. Tujuan penelitian ini adalah untuk mengetahui pengaruh dosis arang sekam dan pupuk kandang terhadap kepadatan populasi dan intensitas serangan $S$. exigua pada tanaman bawang merah. Rancangan yang digunakan dalam penelitian ini adalah Rancangan Acak Kelompok Faktorial (RAK-F) dua faktor dengan faktor pertama yaitu dosis arang sekam (A) dan faktor kedua dosis pupuk kandang sapi (P). Hasilnya menunjukkan bahwa kepadatan populasi dan intensitas serangan larva $S$. exigua tertinggi pada tanaman bawang merah terdapat pada penggunaan dosis arang sekam 60 ton/ha dan pupuk kandang 40 ton/ha. Sedangkan kepadatan populasi dan intensitas serangan terendah terdapat pada perlakuan tanpa arang sekam dan pupuk kandang 20 ton/ha.
\end{abstract}

Kata kunci: Bawang merah, spodoptera exigua, pupuk kandang, arang sekam

\section{ABSTRACT}

Onion plants have a quite complex problems in maintaining production quality caused by plant pests. Plant disturbing organisms is one of the important problems in maintaining the agricultural production. The purpose of this study was to determine the effect of husk charcoal and cow manure dose on the density and intensity of $\underline{S}$. exigua attacks. The design used in this study was a factorial randomized block design (RAK-F) two factors with the first factor being the dose of husk charcoal (A) and the second factor was the dose of cow manure $(P)$. The highest population density of $\underline{S}$. exigua larvae in shallot plants was when 60 ton/Ha husk charcoal and 40 ton/Ha of cow manure was used. Meanwhile the lowest population density of $\underline{S}$. exigua larvae in shallot plants when no husk charcoal was used and 20 ton/Ha of cow manure.

Keywords: Onion plants, Spodoptera exigua, manure fertilizer, husk charcoal

\section{PENDAHULUAN}

Bawang merah merupakan komoditas pertanian yang memiliki nilai ekonomi yang tinggi. Tanaman bawang merah telah tersebar pada semua Propinsi di Indonesia. Luas tanam bawang merah di
Indonesia pada tahun 2016 mencapai 149.635 Ha dengan total produksi 1.446 .680 ton, dan produktivitas rata-rata 9,67 ton/ha. Sedangkan luas tanam di Kabupaten Merauke pada tahun 2016 yaitu 66 Ha dengan total produksi 5.940 ton dan produktivitas rata-rata 9 ton/ha. 
Sebagai komoditas hortikultura yang banyak dikonsumsi masyarakat, bawang merah masih potensial dikembangkan untuk memenuhi kebutuhan dalam negeri dan luar negeri (Statistik, 2012).

Tanaman bawang merah juga memiliki permasalahan yang cukup kompleks dalam mempertahankan hasil mutu produksi. Organisme penggangu tanaman (OPT) merupakan salah satu masalah penting dalam mempertahankan roduksi pertanian. Hama dan penyakit yang belum dapat dikendalikan secara optimal dapat mengakibatkan kerugian yang cukup besar baik berupa kehilangan hasil, penurunan mutu yang secara otomatis langsung menurunkan pendapatan petani. Produktivitas tanaman bawang daun dapat dipertahankan dengan cara ekstensifikasi dan intensifikasi, namun terdapat berbagai kendala yang harus dihadapi. Salah satu kendala untuk meningkatkan produktivitas bawang daun yaitu adanya OPT. OPT adalah setiap organisme yang dapat mengganggu pertumbuhan dan perkembangan tanaman, sehingga tanaman menjadi rusak, pertumbuhannya terhambat, dan atau mati (Sembel, 2011).

S. exigua menjadi salah satu hama penting yang mengakibatkan petani tidak memperoleh hasil produksi maksimal. Penggunaan senyawa kimia pada tanaman bawang merah cenderung berlebihan dan berdampak buruk terhadap lingkungan (Bawang \& Haryati, 2017) serta dapat mengakibatkan kerusakan dan penumpukan logamlogam berat pada tanah. Keberadaan hama $S$. exigua menjadi permasalahan yang sangat merugikan petani bawang merah. Serangga ini dikenal sebagai hama yang polifag. Selain bawang merah, tanaman inang lain dari S. exigua adalah tanaman cabai, kubis, tomat, bayam, kapas, jagung, tembakau, kedelai dan sebagainya (Sari et al., 2017). S. exigua tersebar luas khususnya di daerah tropis dan subtropis, menyerang sepanjang tahun dan serangannya tinggi di musim kemarau. Kerugian yang ditimbulkan akibat serangan S. exigua. pada bawang merah beragam. Menurut Setiawati (1996) kepadatan tiga dan lima larva $S$. exigua perumpun tanaman dapat menyebabkan kehilangan hasil masingmasing sebesar 32 dan $42 \%$. Serangan $S$. exigua pada fase pertumbuhan vegetatif bisa mengakibatkan kehilangan hasil 57100\% (Putrasamedja et al., 2016) dan penurunan kualitas hasil bawang merah yaitu umbi berukuran kecil dan berwarna putih (Febrianasari et al., 2014).

Kerugian yang ditimbulkan akibat serangan S. exigua pada bawang daun dan bawang merah merah jika tidak ditangani secara cepat dan tepat beragam. Kepadatan tiga dan lima larva S. exigua perumpun tanaman bawang merah dapat menyebabkan tanaman tidak dapat berkembang dengan baik. Pada tanaman bawang merah yang berumur 49 hari, serangannya dapat mencapai $62,98 \%$ dengan rata-rata populasi larva 11,52 ekor/rumpun dengan demikian kehilangan hasil berkisar antara 46,56 $56,94 \%$ jika tanaman bawang merah mendapat serangan yang relatif berat pada awal fase pembentukan umbi, maka resiko kegagalan panen akan lebih besar menyebabkan kehilangan hasil panen bawang merah akibat $S$. exigua berkisar 45-47\% (Moekasan, 2012). Bawang merah merupakan komoditi andalan dengan luas panen mencapai 1,222 Ha, produksi 8,659 ton rata-rata 7,09 ton per hektar pertahun. Penelitian mengenai pengaruh dosis arang sekam dan pupuk kandang terhadap kepadatan populasi dan intensitas serangan $S$. exigua pada tanaman bawang merah belum pernah dilakukan. Berdasarkan latar belakang diatas maka penelitian ini perlu dilaksanakan.

\section{METODE}

Penelitian dilaksanakan pada areal budidaya bawang merah di Kampung Isanombias Distrik Tanah Miring Kabupaten Merauke Propinsi Papua. Penelitian berlangsung selama empat bulan, yaitu dimulai pada bulan Januari 
sampai dengan bulan April 2018. Bahanbahan yang digunakan dalam penelitian ini adalah bibit bawang merah varietas Bauji, arang sekam, pupuk kandang sapi, serta pupuk kimia. Alat yang digunakan dalam penelitian ini antara lain adalah cangkul, parang, tugal, rol meter, tali, ember, patok, sprayer, terpal, gunting, karung, timbangan, penggaris dan alat tulis. Rancangan yang digunakan dalam penelitian ini adalah menggunakan Rancangan Acak Kelompok Faktorial (RAK-F) 2 faktor dengan faktor pertama yaitu dosis arang sekam (A) dan faktor kedua dosis pupuk kandang sapi (P). Faktor pertama terdiri dari empat taraf yaitu :

A0 $=$ Tanpa Arang sekam,

$\mathrm{A} 1=2 \mathrm{Kg}$ arang sekam/plot percobaan atau setara dengan 20 ton/ha,

A2 $=4 \mathrm{Kg}$ arang sekam/plot percobaan atau setara dengan 40 ton/ha,

$\mathrm{A} 3=6 \mathrm{Kg}$ arang sekam/plot percobaan atau setara dengan 60 ton/ha.

Faktor kedua terdiri dari 4 taraf yaitu: P0 = Tanpa Pupuk kandang,

$\mathrm{P} 1=2 \mathrm{Kg}$ Pupuk kandang/plot percobaan atau setara dengan 20 ton/ha,

P2 $=3 \mathrm{Kg}$ Pupuk kandang/plot percobaan atau setara dengan 30 ton/ha,

P3 $=4 \mathrm{Kg}$ Pupuk kandang/plot percobaan atau setara dengan 40 ton/ha.

Masing masing perlakuan diulang sebanyak 3 kali ulangan sehingga akan diperoleh 48 plot percobaan. Lebar bedengan $1 \mathrm{~m}$ dan panjang $1 \mathrm{~m}$. Jarak tanam yang digunakan $10 \mathrm{~cm} \times 20 \mathrm{~cm}$ sehingga dalam setiap plot terdiri dari 50 tanaman dan diperoleh 2400 tanaman. Jumlah tanaman yang akan dijadikan sampel yaitu $10 \%$ dari jumlah total tanaman sehingga diperoleh 240 tanaman sampel dan 5 tanaman pada setiap plot percobaan. Persentase serangan hama pada masing-masing bagian tanaman bawang yang diamati dihitung dengan menggunakan rumus :

$$
P=r / R \times 100 \%
$$

$\mathrm{P}=$ persentase serangan

$\mathrm{r}=$ jumlah rumpun yang terserang

$\mathrm{R}=$ total tanaman

Dosis pupuk yang digunakan yaitu Phonska $800 \mathrm{~kg} / \mathrm{ha}$ dan ZA $400 \mathrm{~kg} / \mathrm{ha}$. Pemupukan dasar dilakukan saat pengolahan tanah kedua dengan mencampurkan pupuk kandang sapi dan arang sekam pada plot percobaan sesuai dosis kombinasi yang telah ditetapan. Pemupukan susulan dilakukan dua tahap yaitu pada 1 minggu setelah tanam, diberikan $1 / 2$ dari dosis pupuk per hektar yaitu Phonska $400 \mathrm{~kg} / \mathrm{ha}$ atau $40 \mathrm{~g} / \mathrm{plot}$ dan ZA $200 \mathrm{~kg} / \mathrm{ha}$ atau $20 \mathrm{~g} / \mathrm{plot}$. Pemupukan susulan kedua diberikan pada 4 minggu setelah tanam, diberikan $1 / 2$ dari dosis pupuk per hektar yaitu Phonska $400 \mathrm{~kg} / \mathrm{ha}$ atau $40 \mathrm{~g} / \mathrm{plot}$ dan ZA $200 \mathrm{~kg} / \mathrm{ha}$ atau $20 \mathrm{~g} / \mathrm{plot}$. Pengamatan dilakukan pada minggu ke 2, 4, 6 s setelah tanam.

\section{HASIL DAN PEMBAHASAN}

\section{Kepadatan Populasi Spodoptera exigua}

Salah satu hama yang merusak tanaman bawang merah di Distrik Tanah Miring adalah ulat bawang Spodoptera exigua. Larva berbentuk bulat panjang, berwarna hijau atau coklat dengan kepala berwarna kuning kehijauan. Stadium larva berlangsung sekitar 2 minggu yang terdiri dari 5 instar. Ukuran rata-rata larva ini antara $20 \mathrm{~mm}$. Ciri khas dari larva $S$. exigua memiliki garis-garis hitam pada punggungnya. Suhu, kelembaban, dan keadaan cuaca sangat mempengaruhi kepadatan populasi $S$. exigua. Hama tersebut memiliki kemampuan menyebar cepat pada tanaman bawang merah dan bawang daun di dataran rendah dan dataran tinggi, selain itu hama tersebut menyerang tanaman sepanjang tahun baik musim kemarau maupun musim hujan (Moekasan, 2012). 


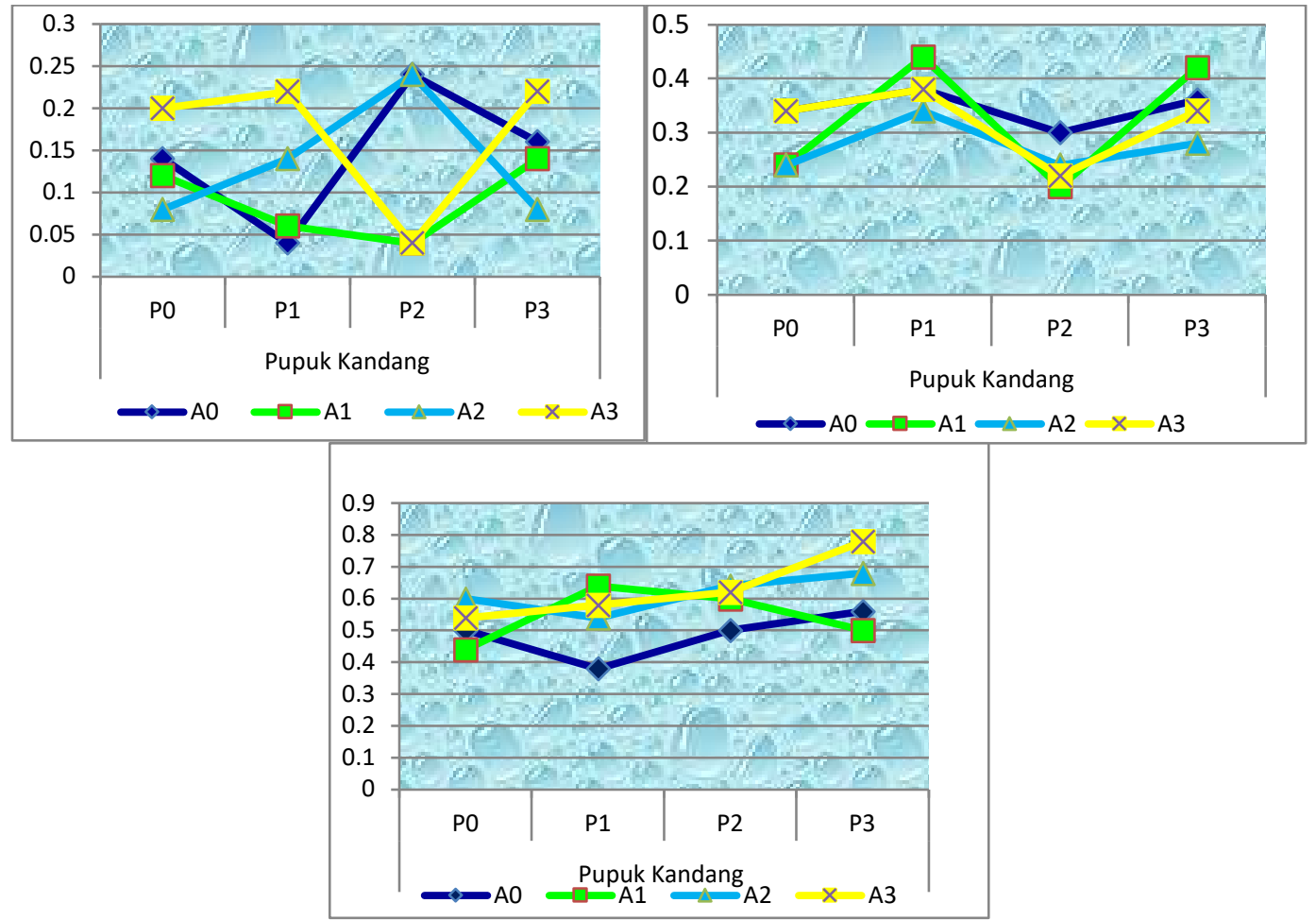

Gambar 1. Kepadatan populasi Spodoptera exigua pada setiap perlakuan

Kepadatan populasi S. exigua pada 2 minggu setelah tanam (MST) paling tinggi terdapat pada perlakuan A0P2 $(0,24)$ dan terendah A3P2 $(0,04)$ (Gambar 1A). Pada 2 MST, rata-rata populasi S. exigua masih tersebar secara merata pada seluruh tanaman. Hal ini disebabkan karena bawang merah masih berada pada fase awal pertumbuhan dimana jumlah daun relatif masih sama. Kepadatan populasi $S$. exigua pada 4 MST yang paling tinggi terdapat pada A1P1 $(0,44)$, dan terendah A1P2 $(0,20)$ (Gambar 1B). Pada umumnya kepadatan populasi $S$. exigua pada 4 MST lebih tinggi pada perlakukan arang sekam atau pupuk kandang dengan dosis yang lebih besar. Hal ini disebabkan karena pemberian arang sekam atau pupuk kandang dengan dosis yang besar memengaruhi jumlah daun. Setelah tanaman berumur 6 MST kepadatan populasi yang paling tinggi terdapat pada perlakuan A3P3 $(0,78)$ dan terendah A0P1 $(0,38)$ (Gambar 1C). Perlakuan kombinasi yang tinggi mengakibatkan petumbuhan tanaman menjadi baik dengan batang yang lebih besar dan jumlah daun yang banyak. Hal ini mendukung ketersedian nutrisi bagi S.exigua. Selain itu jumlah daun yang banyak dapat memengaruhi suhu dan kelembapan sekitar tanaman yang menguntungkan bagi serangga. Populasi $S$. exigua dipengaruhi oleh beberapa faktor diantaranya siklus hidup, ketersediaan makanan, faktor lingkungan, dan predator. Padatnya populasi $S$. exigua pada bawang merah umur 6 MST dipengaruhi oleh siklus hidup dari $S$. exigua ini, karena pada bawang merah umur $6 \mathrm{MST}$, telur $S$. exigua telah banyak menetas menjadi larva. 


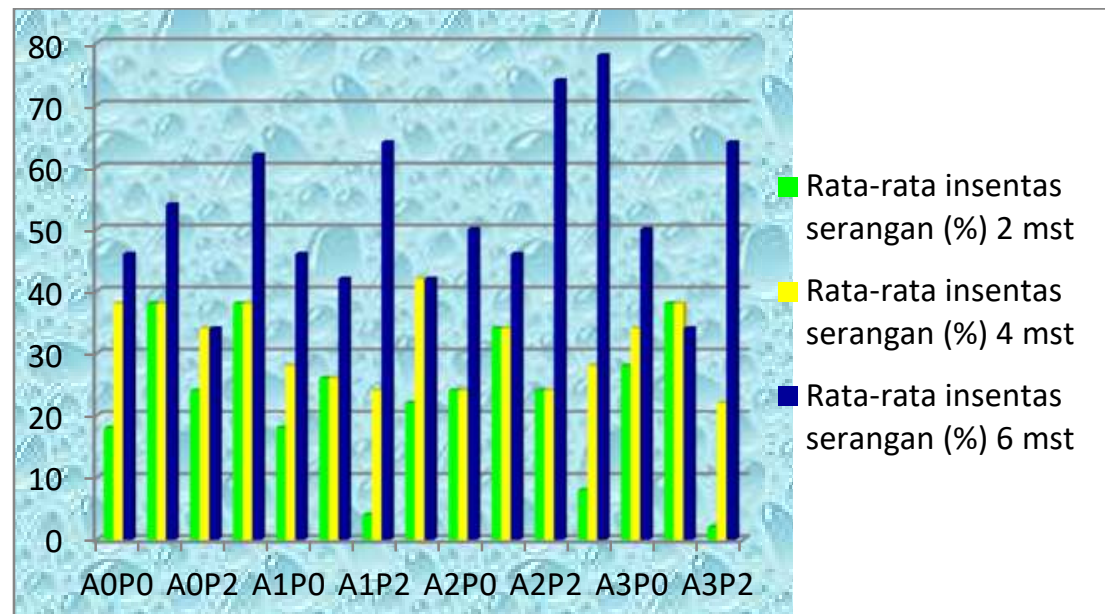

Gambar 2. Intensitas Serangan Spodoptera exigua pada setiap perlakuan

Intensitas serangan S. exigua pada 2 MST tertinggi terdapat pada A3P0 (28\%) dan terendah A3P2 (2\%). Pada pengamatan 4 MST intensitas serangan tertinggi pada A1P3 (42\%) dan terendah A3P2 (22\%). Intensitas serangan pada 6 MST tertinggi terdapat pada A3P3 (82\%) dan A0P2 (34\%). Pada 2 MST populasi hama $S$. exigua sudah banyak bermunculan dan terus meningkat pada setiap umur tanaman di tanaman bawang merah. Kepadatan empat sampai enam larva $S$. exigua per rumpun dalam tanaman bawah merah dapat menyebabkan kehilangan hasil karena daun bawang merah akan habis. Selain itu juga menyebabkan kematian pada bawang merah dan memengaruhi produksi. Pada umumnya populasi $S$. exigua yang paling padat pada 4 MST terjadi pada tanaman dengan perlakuan arang sekam atau pupuk kandang dengan dosis yang lebih tinggi. Hal ini dipengaruhi karena pemberian arang sekam atau pupuk kandang dengan dosis yang tinggi akan memengaruhi jumlah daun pada tanaman bawang merah. Setelah tanaman berumur 6 MST, kepadatan populasi yang paling tinggi terjadi pada perlakuan A3P3 $(0,78)$ dan terendah A0P1 $(0,38)$.

Penggunaan insektisida yang berlebihan juga dapat membuat hama yang dulunya peka menjadi tahan terhadap insektisida karena penggunaan pestisida yang tidak sesuai dosis dan aturan yang menyebabkan banyak hama tanaman pertanian menjadi resisten dan sulit dikendalikan dengan pestisida. Penggunaan pestisida kimia yang tidak bijaksana pada tanaman bawang merah dapat menyebabkan matinya musuh alami (Woodford, 1984) serta terjadinya pencemaran terhadap lingkungan yang berakibat kurang baik terhadap kesehatan manusia (Mu, 2019). Tanaman bawang merah selain rentan serangan hama $S$ exigua juga penyakit layu Fusarium $s p$ yang menyebabkan layu. Pada umur bawang merah 6 MST kepadatan populasi $S$. exigua mencapai puncak. Hal ini karena siklus hidup dari $S$. exigua. Pada umur ini telur $S$. exigua sudah banyak yang menjadi larva. Selain itu juga dipengaruhi persediaan nutrisi yang mulai berkurang karena pertumbuhan daun bawang merah pada umur ini telah berhenti dan sebagian daunnya sudah mulai tua atau kering. Hal itu mengakibatkan adanya kompetisi antar serangga untuk memperebutkan ruang dan makanan. Selain itu keadaan cuaca yang kurang mendukung juga mempengaruhi kepadatan populasi $S$. exigua, Pada umur bawang merah 6 MST, keadaan cuaca di lokasi penelitian gerimis, dengan suhu $25^{\circ} \mathrm{C}$ dan kelembaban $85 \%$. Jika kondisi cuaca tidak menguntungkan atau gerimis, besar kemungkinan telur-telur $S$. exigua akan jatuh dari daun bawang merah. Perkembangan populasi $S$. exigua pada bawang merah lebih tinggi pada musim 
kemarau daripada musim hujan. Hal ini disebabkan karena curah hujan yang tinggi menyebabkan menurunnya populasi $S$. exigua akibat tercuci oleh hujan, selain itu aktivitas hama ini akan menurun ketika hujan turun (Sakinah, 2013).

\section{Korelasi antara Kepadatan Populasi dengan Intensitas Serangan}

Kepadatan populasi yang tinggi akan berjalan lurus atau berbanding positif dengan intensitas serangan. Kepadatan populasi yang tinggi akan mengakibatkan intensitas serangan yang tinggi. Hal ini berkaitan dengan sumber daya lingkungan dalam hal ini ketersedian daun sebagai makanan dan tempat berlindung. Hama ini merusak saat stadium larva, yaitu melubangi serta memakan daun. Biasanya dalam jumlah yang banyak atau besar larva ini bersama-sama pindah dari tanaman yang telah habis dimakan daunnya ke tanaman lainnya.

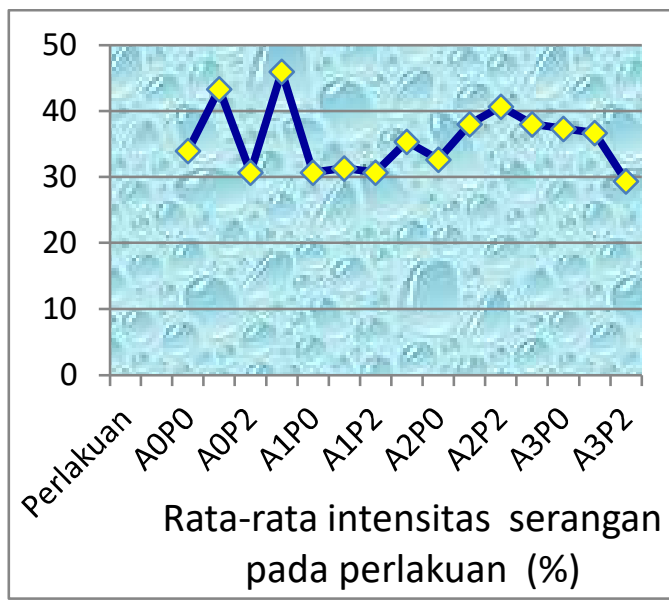

A

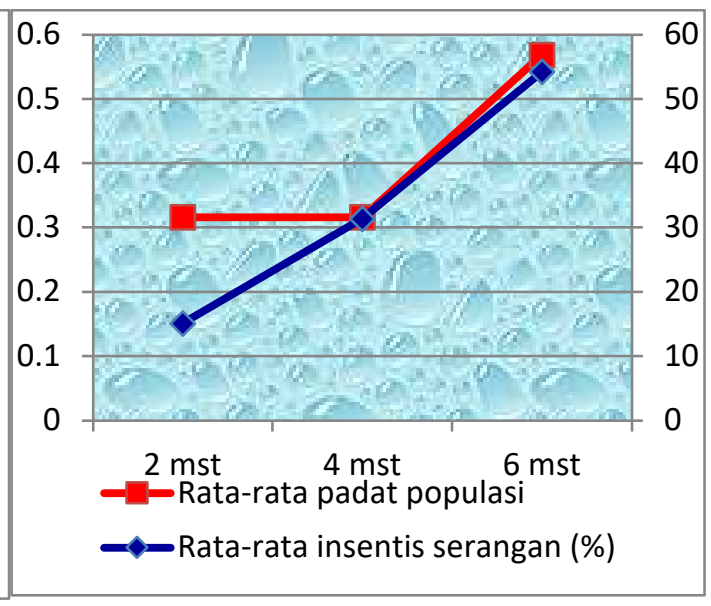

B

Gambar 3. A. Korelasi rata-rata padat populasi dengan intensitas serangan

B. Rata-rata intensitas serangan pada perlakuan

Kerimbunan daun pada tanaman dapat dimanfaatkan oleh sejumlah serangga sebagai tempat berlindung dari matahari dan ataupun dari serangan musuh alaminya (sembel, 2006). Hal ini bisa terlihat dari perlakuan $\mathrm{A} 3 \mathrm{P} 3$ dengan jumlah daun mencapai 30 daun per umpun dengan intensitas serangan mencapai 50\%. Berdasarkan hasil pengamatan di lapangan, larva $S$. exigua menyerang tanaman bawang merah dengan gejala umum larva menggerek daun dan membuat lubang pada ujung daun dengan memakan bagian dalam daun sehingga daun terlihat menerawang dan hanya tersisa epidermis daun saja, pada serangan berat daun akan terpotongpotong/jatuh terkulai. Selain itu kondisi pertanaman bawang merah pada saat penelitian rawan dengan penyakit layu fusarium atau masyarakat lokal menyebutnya "inul" yang menyerang hampir seluruh pertanaman di sentral lokasi pertanaman bawang merah di Distrik Tanah Miring. Ketahanan tanaman lebih rendah karena temperatur yang tinggi mengakibatkan penurunan kualitas vigor dan fisiologis tanaman serta merupakan suhu yang optimum untuk perkembangan $S$. exigua (Febrianasari et al., 2014). Penggunaan insektisida sintetik untuk pengendalian $S$. exigua sering menimbulkan masalah diantaranya adalah pembengkakan biaya perawatan karena pembelian insektisida sintetik yang mahal (Febrianasari et al., 2014). Disamping harga insektisida sintetik yang mahal dan hama yang 
semakin resisten dengan insektisida yang digunakan, maka petani lebih memilih pengendalian secara mekanik contohnya adalah dengan menggunakan jaring (sweeping) (Darmawan et al., 2013).

\section{SIMPULAN}

Kepadatan populasi dan intensitas serangan larva $S$. exigua tertinggi pada tanaman bawang merah terdapat pada penggunaan dosis arang sekam 60 ton/ha dan pupuk kandang 40 ton/ha. Sedangkan kepadatan populasi dan intensitas serangan terendah terdapat pada perlakuan tanpa arang sekam dan pupuk kandang 20 ton/ha.

\section{UCAPAN TERIMA KASIH}

Penulis Mengucapkan terimakasih kepada Petani bawang Merah Distrik Tanah Miring yang telah membantu dalam penelitian ini

\section{DAFTAR PUSTAKA}

Anggarayasa, C., Sri, M., Agung, A., Putri, S., \& Andriani, R. (2018). Pengaruh Jarak Tanam dan Pupuk Kompos pada Pertumbuhan dan Hasil Tanaman Bawang Merah. 23(2), 162166.

Badan Pusat Statistik, (2017). Merauke Dalam Angka (Issue 09).

Bawang, P., \& Haryati, Y. (2017). Peluang Pengembangan Feromon Seks Dalam Pengendalian Hama Ulat Bawang (Spodoptera exigua) Pada Bawang Merah. 28(2), 72-77. https://doi.org/10.21082/jp3.v28n2.2 009.p72

Cakra, I. P., \& Adnyana, P. (2016). Respon Bawang Merah ( Allium cepa L ) terhadap Biochar Sekam, Trichoderma Sp dan Aplikasi Pupuk Anorganik Dosis Rendah. 1, 936941.

Conte, P. (2014). Biochar, soil fertility, and environment. Biology and Fertility of Soils, 50(8), 90128. https://doi.org/10.1007/s00374-0140973-0
Darmawan, W. E. B., Himawan, T., Tarno, H., \& Sutrisno, H. (2013). Identifikasi Beberapa JenisNgengat Jantan Genus Arctornis (Lepidoptera: Noctuoidea) Di Indonesia Berdasarkan Karakter Morfologi Dan Genitalia. Jurnal HPT Volume 1 No. 4 ISSN : 2338 - 4336, 1, 42-50.

Dewi, P. M. S., \& Ariffin. (2019). Pengaruh Naungan dan Media Tanam terhadap Pertumbuhan dan Hasil Produksi Tanaman Bawang Merah (Allium ascalonicum L.) pada Sistem Budidaya Hidroponik The Effect of Shade and Growing Media on Growth and Yield Production of Shallots (Allium ascalonicum L.) . Jurnal Produksi Tanaman, 7(3), 511-517.

Febrianasari, R., Tarno, H., \& Afandhi, A. (2014). Efektivitas Klorantraniliprol Dan Flubendiamid Pada Ulat Bawang Merah ( Spodoptera exigua Hubner) (Lepidoptera: Noctuidae). Jurnal HPT, 2, 103-109. https://doi.org/10.1115/1.1521166

Herman, w., \& Resigia, E. (2018). Pemanfaatan biochar sekam dan kompos jerami padi terhadap pertumbuhan dan produksi padi (oryza sativa) pada tanah ordo ultisol. Jurnal Ilmiah Pertanian, 15(1), 42-50. https://doi.org/10.31849/jip.v15i1.14 87

Indonesia, D. (2016). Pengelolaan Tanaman Dan Tumbuhan Inang Untuk Pengendalian Thrips Pada Tanaman Kacang Hijau. Pengelolaan Tanaman Dan Tumbuhan Inang Untuk Pengendalian Thrips Pada Tanaman Kacang Hijau, 45(29), 3345. $\quad$ https://doi.org/10.21082 /bulpa.v0n29 .2015.p33-45

Irawan, A., Jufri, Y., \& Zuraida. (2016). Sifat Kimia Andisol, Pertumbuhan dan Produksi Gandum ( Triticum eastivum L .). Jurnal Kawista, 1(1), 19.

Jumar. (2000). Koleksi Buku 2000 Entomologi pertanian / Jumar. 115.

Kinasih, I., Kusumorini, A., Cahyanto, T., \& Arofah, N. (2013). Tingkat Reproduksi Jangkrik Ciriling ( Grillus 
mitratus Burm .). 6(April), 66-72. https://doi.org/10.15408/al-

kauniyah.v6i1.2831

Kurniawan, A., Haryono, B., Baskara, M., \& Tyasmoro, S. Y. (2016). Pengaruh penggunaan Biochar Pada Media Tanam Terhadap Pertumbuhan Bibit Tanaman Tebu ( Saccharum officinarum 1.) the effects of biochar application to planting media on the growth of sugarcane seeds ( Saccharum officinarum L .). Jurnal Produksi Tanaman, 4(2), 153-160.

Laginda, Y. S. (2017). Aplikasi Pupuk Organik Cair Berbahan Dasar Batang Pisang Terhadap Pertumbuhan Dan Produksi Tanaman Tomat ( Lycopersicum Esculentum Mill .) Application of Liquid Organic Fertilizer Made from Banana Stem on Grow and Production of Tomato Plant ( Lycopersicum. Jurnal Galung Tropika, 6(2), 81-92.

Moekasan, T. (2012). Penerapan Ambang Pengendalian Organisme Pengganggu Tumbuhan pada Budidaya Bawang Merah dalam Upaya Mengurangi Penggunaan Pestisida. Jurnal Hortikultura, 22(1), 47.

https://doi.org/10.21082/jhort.v22n1. 2012.p47-56

Moekasan, T. K., Setiawati, W., Hasan, F., Runa, R., \& Somantri, A. (2013). Penetapan Ambang Pengendalian Spodoptera exigua pada Tanaman Bawang Merah Menggunakan Feromonoid Seks. Jurnal Hortikultura, $23(1), \quad 80$. https://doi.org/10.21082/jhort.v23n1. 2013.p80-90

Mu, A. (2019). No Title No Title. Journal of Chemical Information and Modeling, 53(9), 1689-1699. https://doi.org/10.1017/CBO9781107 415324.004

Onggo, T. M., Kusumiyati, K., \& Nurfitriana, A. (2017). Pengaruh penambahan arang sekam dan ukuran polybag terhadap pertumbuhan dan hasil tanaman tomat kultivar 'Valouro' hasil sambung batang. Kultivasi, 16(1), 298-304. https://doi.org/10.24198/kultivasi.v1 6i1.11716

Pertumbuhan, T., \& Produksi, D. A. N. (2014). 1 , 2 , 2. 1-12.

Putrasamedja, S., Setiawati, W., Lukman, L., \& Hasyim, A. (2016). Penampilan Beberapa Klon Bawang Merah dan Hubungannya dengan Intensitas Serangan Organisme Pengganggu Tumbuhan. Jurnal Hortikultura, $22(4), \quad 349$. https://doi.org/10.21082/jhort.v22n4. 2012.p349-359

Sakinah, F. (2013). Serangan Organisme Pengganggu Tanaman ( Opt ) Pada Tanaman Bawang Merah. 3.

Sari, Y. M., Prastowo, S., \& Haryadi, T. (2017). Uji Ketertarikan Ngengat Spodoptera exigua Hubn. terhadap Perangkap Lampu Warna pada Pertanaman Bawang Merah (Allium ascalonicum L.). Agrovigor: Jurnal Agroekoteknologi, 10(1), 1-6. https://doi.org/ 10.21107 /agrovigor. v10i1.2366

Sembel. D.T(2010.). Pengendalian Hayati : Hama-hama Serangga Tropis dan Gulma, Sejarah dan Luang Lingkup, Jenis dan Karakter Musuh Alami, Prosedur Pengendalian Yogyakarta : ANDI, 2010

Sihotang, T., \& Rauf, A. (2018). Pengaruh Pemberian Biochar Dari Beberapa Bahan Baku Dan Produksi Tanaman Bawangmerah ( Allium ascalonicum L .) Di lahan sawah. 2(2), 206-211.

Studi, P., Fakultas, A., \& Universitas, P. (2016). the Effect of Biochar and Npk Toward Some. 2(2), 15-26.

Sodig M, (2015). Ketahanan Tanaman Universitas Pembangunan Nasioanal Veteran Fakultas Pertanian Dk, 53(9), 1689-1699. https://doi.org/10.1017/CBO9781107 415324.004

Woodford, J. A. T. (1984). Pests of crops in Indonesia. In Crop Protection (Vol. 3 , Issue 1, pp. 127-129). https://doi.org/10.1016/02612194(84)90018-8

Xu. Wenhua, E. H. Han, Wang Zhenyu (2015). Effect of tannic acid on 
corrosion behavior of carbon steel in $\mathrm{NaCl}$ solution

DOI:10.1016/J.JMST.2018.09.001

Yang, X., Liu, J., McGrouther, K., Huang, H., Lu, K., Guo, X., He, L., Lin, X., Che, L., Ye, Z., \& Wang, H. (2016). Effect of biochar on the extractability of heavy metals $(\mathrm{Cd}$, $\mathrm{Cu}, \mathrm{Pb}$, and $\mathrm{Zn}$ ) and enzyme activity in soil. Environmental Science and Pollution Research, 23(2), 974-984. https://doi.org/10.1007/s11356-0154233-0 
Jurnal Agrosains dan Teknologi Volume 6 Nomor 1 Juni 2021

p-ISSN 2528-0201

website : jurnal.umj.ac.id/index.php/ftan

e-ISSN 2528-3278 